\title{
Individual differences in relational motives interact with the political context to produce terrorism and terrorism-support
}

\section{Citation}

Thomsen, Lotte, Milan Obaidi, Jennifer Sheehy-Skeffington, Nour Kteily, and Jim Sidanius. 2014. "Individual Differences in Relational Motives Interact with the Political Context to Produce Terrorism and Terrorism-Support." Behav Brain Sci 37 (04) (August): 377-378. doi:10.1017/ s0140525x13003579.

\section{Published Version}

doi:10.1017/S0140525X13003579

\section{Permanent link}

http://nrs.harvard.edu/urn-3:HUL.InstRepos:14302019

\section{Terms of Use}

This article was downloaded from Harvard University's DASH repository, and is made available under the terms and conditions applicable to Open Access Policy Articles, as set forth at http:// nrs.harvard.edu/urn-3:HUL.InstRepos:dash.current.terms-of-use\#OAP

\section{Share Your Story}

The Harvard community has made this article openly available.

Please share how this access benefits you. Submit a story.

Accessibility 
LANKFORD

\author{
Abstract (59 words) \\ Main text (1000 words) \\ References (518 Words) \\ Entire text (1688 Words)
}

\title{
Individual differences in relational motives interact with the political context to produce terrorism and terrorism-support
}

\author{
Lotte Thomsen \\ University of Oslo, University of Copenhagen, Harvard University \\ Milan Obaidi \\ European University Institute, Harvard University \\ Jennifer Sheehy-Skeffington \\ Harvard University \\ Nour Kteily \\ Harvard University \\ Jim Sidanius \\ Harvard University
}




\section{LANKFORD}

\section{ADDRESSES:}

Lotte Thomsen, Department of Psychology, University of Oslo, PO Box 1094 Blindern, 0317 Oslo, Norway. Phone +452530267. Email

lotte.thomsen@psykologi.uio.no. URL:

http://harvard.academia.edu/LotteThomsen

Milan Obaidi, Department of Psychology, Harvard University, William James Hall, 33 Kirkland Street, Cambridge, MA 02138. Email Milan.Obaidi@eui.eu

Jennifer Sheehy-Skeffington, Department of Psychology, Harvard University, William James Hall, 33 Kirkland Street, Cambridge, MA 02138. Email jsheehy@fas.harvard.edu, URL:

http://harvard.academia.edu/JenniferSheehySkeffington

Nour Kteily, Department of Psychology, Harvard University, William James Hall, 33 Kirkland Street, Cambridge, MA 02138. Email nkteily@fas.harvard.edu, URL: http://scholar.harvard.edu/nkteily/links/publications

Jim Sidanius, Department of Psychology, Harvard University, William James Hall, 33 Kirkland Street, Cambridge, MA 02138. Email sidanius@wjh.harvard.edu URL:

http://projects.iq.harvard.edu/sidaniuslab/people/jim-sidanius 


\title{
LANKFORD
}

\begin{abstract}
The psychology of suicide terrorism involves more than simply the psychology of suicide. Individual differences in Social Dominance Orientation (SDO) interact with socio-structural, political context to produce support for group-based dominance among members of both dominant and subordinate groups. This may help explain why, in one specific context, some people commit and endorse terrorism, while others do not.
\end{abstract}




\section{LANKFORD}

We agree with Lankford that one cannot understand suicide terrorism without considering individual factors as well as contextual ones, and must distinguish perpetrator from audience effects.

Nevertheless, while being willing to kill oneself is a necessary condition for carrying out suicide bombings, this need not imply that what really drives suicide bombers, rampage shooters and other self-destructive killers is simply suicidality proper, conveniently disguised as political terrorism in cultural and religious contexts that ban individual suicide. In the case studies he uses to make the latter point, Lankford not only seeks to estimate reliable predictors of suicide-such as prior suicide attempts, expressed death wishes, and debilitating depression-but also includes many "soft" risk factors such as the deaths of parents or siblings in childhood, unemployment, divorce due to infertility, and even disciplinary problems in school. Without knowing the base rates of both kinds of factors among the general population, it is impossible to evaluate the degree to which they lead people to commit suicide, let alone suicide terrorism, particularly when considered in the often war-torn, occupied settings from which Lankford draws many cases. Just as a suicidal mental condition is insufficient to drive suicide terrorism, so it may likely be unnecessary. The case of Anders Behring Breivik-who shot 77 teenagers at a political youth camp after seeking to blow up the Norwegian governmental building-demonstrates the uncertainty of clinical judgments based on interpretations of written or limited data records. Though Lankford concludes that Breivik was clearly suicidal because his writings named the plight of conservative 


\section{LANKFORD}

"brothers and sisters" being pushed toward suicide, and anticipated dying during his terror mission, a final forensic-psychiatric assessment, following extensive clinical interviews and 24-hour-observations, not only concluded that Breivik was not psychotic, but found absolutely no evidence that he was suicidal (NTB, 2012). Indeed, Breivik expressed fear of getting killed by the police upon being taken captive.

What clearly is necessary for committing any such acts of terrorism is the willingness to kill civilian others. We agree that this homicidal intent is likely fueled by rage and that cultural and ideological endorsement facilitates suicide terrorism. But both respond to the political reality in which a community finds itself. For instance, Pape (2005) argues that suicide terrorist attacks in Lebanon ebbed and flowed with the absence and presence of Israeli occupation (while suicidal intent presumably remained fairly stable). Dismissing this as simply about increased access to weapons and enemy targets ignores the role of the political context in fueling rage towards an enemy group-relationally motivated, moral outrage (Rai \& Fiske, 2011) that they are subordinating, humiliating, discriminating, victimizing, persecuting, and killing us, or threatening to do so, culminating in the intended killing of perceived enemy civilians.

Such political context effects may play a role even in cases of remote identification with group members suffering at times of conflict or oppression (SheehySkeffington, 2009). For instance, we recently found that support for a variety of terrorism-related items among Muslim citizens living in Denmark, ranging from 


\section{LANKFORD}

general understanding of terrorism to personal willingness to use violence to defend Islam, was predicted by perceptions of general Muslim suffering, and was mediated by the anger this suffering evoked (Obaidi, Thomsen, \& Sidanius, 2013). These victimization-by-proxy effects were even stronger among Danish-born than foreign—born Muslims (Sidanius, Levin, Obaidi, Pratto, \& Thomsen, 2013), and held even when controlling for the effects of personal experiences of discrimination, a structural factor indicated in radicalization among British Muslims (Travis, 2008).

In understanding how individual factors play into these processes, such that some people in a specific context endorse or commit acts of terrorism while others in the same context do not, we must go beyond the biographical and psycho-pathological to the relational and ideological/political. The degrees to which people like, want and seek relationships that are communal, hierarchical, or egalitarian underpin many psychological phenomena (Thomsen, 2010). One particularly potent dimension of relational motives is social dominance orientation (SDO) - the motivation to create and maintain between-group dominance hierarchies (Pratto, Sidanius, Stallworth, \& Malle, 1994). Individuals high in SDO support hierarchical intergroup structures, in which some groups dominate others, whereas individuals low in SDO favor intergroup equality. These motives, and the cultural context that embeds them, influence both the societal endorsement of suicide terrorism, and the attitudes of those willing to commit it themselves. For instance, by looking at the negative relationship between SDO and support for terrorism against the West amongst Lebanese and Syrians, our work has demonstrated that counter-dominance is an important ideological motivation undergirding support for terrorism against 


\section{LANKFORD}

dominant groups (Levin, Henry, Pratto, \& Sidanius, 2003; Henry, Sidanius, Levin, \& Pratto, 2005; Pratto, Sidanius, Bou-Zeinnedine, Kteily, \& Levin, in press). Conversely, among members of dominant majority groups in the West, the desire for groupbased dominance increases support for violence, wars of conquests, and terrorist acts in retaliation against a threatening group or country (Thomsen, Green, \& Sidanius, 2008; Ho, Sidanius, Pratto, Levin, Thomsen, Kteily, \& Sheehy-Skeffington, 2012). Further supporting the crucial interaction of individual, relational motives and the structural context, the effect of group identification on terror support among subordinate groups (e.g. of Arab identification among Lebanese) is particularly strong among those who are low in SDO, whereas identification with dominant groups (e.g. national identification among Americans) particularly increases support for violence among those high in SDO (Levin et al, 2003; Kteily et al, 2013; Thomsen, Green, \& Sidanius, 2013). Again, Breivik's self-described radical identification with a Christian in-group and desire to preserve its dominance would fit this picture.

In sum, we concur that it is crucial to consider both the person and the situation in understanding suicide terrorism. Research and theory in the Social Dominance tradition explicates how individual differences in relational motives interact dynamically with the socio-structural context in shaping people's attitudes towards actions of group-based violence. Just as social psychology involves more than just the situation, and individual differences more than just the psychopathological, so the psychology of suicide terrorism is more than simply the psychology of suicide. 


\section{LANKFORD}

\section{References}

Henry, P. J., Sidanius, J., Levin, S., \& Pratto, F. (2005). Social dominance orientation, authoritarianism, and support for intergroup violence between the Middle East and America. Political Psychology, 26(4), 569-584.

Ho, A. K., Sidanius, J., Pratto, F., Levin, S., \& Thomsen, L., Kteily, N., \& SheehySkeffington (2012) Social Dominance Orientation: Revisiting the structure and function of a variable predicting social and political attitudes. Personality and Social Psychology Bulletin, 38, 583

Kteily, N. S., Sidanius, J., \& Levin, S. (2011). Social dominance orientation: Cause or "mere effect"? Evidence for SDO as a causal predictor of prejudice and discrimination against ethnic and racial outgroups. Journal of Experimental Social Psychology, 47, 208-214.

Kteily, N., Sidanius, J., Pratto, F., Levin, S., \& Saab, R. (2013). Social dominance orientation and group identification predict support for non- normative violence in tandem. Manuscript in preparation.

Levin, S., Henry, P. J., Pratto, F., \& Sidanius, J. (2003). Social dominance and social identity in Lebanon: Implications for support of violence against the West. Group Processes \& Intergroup Relations, 6(4), 353-368.

NTB (2012). Breivik uten empati, men ikke psykotisk (Breivik without empathy, but not psychotic). Available at http://dt.no/nyheter/breivik-uten-empati-men-ikkepsykotisk-1.7175030

Obaidi, M., Thomsen, L. \& Sidanius, J. (2013). I am ready to kill: The effects of religious victimization and social dominance orientation on terror support among Muslim immigrants living in Denmark. Manuscript in preparation.

Pratto, F., Sidanius, J., \& Levin, S. (2006). Social dominance theory and the dynamics of intergroup relations: Taking stock and looking forward. European review of social psychology, 17(1), 271-320.

Pratto, F., Sidanius, J., Bou Zeinnedine, F., Kteily, N., \& Levin, S. (in press). When domestic politics and international relations intermesh: Subordinated publics' factional support within layered power structures. Foreign Policy Analysis.

Sheehy-Skeffington, J. (2009). Social psychological motivations of suicide terrorism: A community level perspective. Online proceedings of the 2009 Annual Scientific Meeting of the International Society for Political Psychology, Dublin, Ireland.

Sidanius, J., Kteily, N. S., Sheehy-Skeffington, J., Ho, A. K., Sibley, C. \& Duriez, B. (2013). "You're inferior and not worth our concern." The reciprocal 


\section{LANKFORD}

relationship between empathic concern and social dominance orientation. Journal of Personality, 81, 313-323.

Sidanius, J., Levin, S.,Obaidi, M., Pratto, F., \& Thomsen, L. (2013). Why do they hate us so? Paper presented at the $3^{\text {th }}$ Annuak Scientific Meeting of the International Society of Political Psychology, Herzliya, Israel.

Thomsen, L. (2010). Seeing Social Relations. Doctoral Dissertation, Harvard University.

Thomsen, L., Green, E., \& Sidanius, J. (2008). We Will Hunt Them Down: How social dominance Orientation and right-wing authoritarianism fuel ethnic persecution of immigrants in fundamentally different ways. Journal of Experimental Social Psychology, 44, 1455-1464.

Thomsen, L., Green, E.G.T., \& Sidanius, J. (2013). Religion Hi-jacked: SDO interacts with religious identification among Christians to predict willingness to persecute assimilating Muslims. Manuscript in preparation.

Travis, A. (2008). MI5 report challenges views on terrorism in Britain. Available at: http://www.theguardian.com/uk/2008/aug/20/uksecurity.terrorism1. 